Article

\title{
Development of Changeover Operating Method Based on Performance Prediction of Hybrid Geothermal Heat Pump Systems through Field Test and Numerical Analysis
}

\author{
Ji-Hyun Shin ${ }^{1}$, Yoon-Bok Seong ${ }^{2}$, Yong-In Kim ${ }^{3}$ and Young-Hum Cho ${ }^{4, *}$ \\ 1 Department of Architectural Engineering, Graduate School of Yeungnam University, 280 Daehak-Ro, \\ Gyeongsan, Gyeongbuk 38541, Korea; sjh1010@ynu.ac.kr \\ 2 Korea Conformity Laboratories, Seoul 06711, Korea; nike21@snu.ac.kr \\ 3 Now Consulting Engineers Co. LTD, Seoul 05073, Korea; nowmec@chol.com \\ 4 School of Architecture, Yeungnam University, 280 Daehak-Ro, Gyeongsan, Gyeongbuk 38541, Korea \\ * Correspondence: yhcho@ynu.ac.kr; Tel./Fax: +82-53-810-3081
}

Received: 1 September 2020; Accepted: 29 September 2020; Published: 13 October 2020

check for updates

\begin{abstract}
The installation and operation of geothermal systems increased due to the expectation of good cooling and heating performance due to stable heat source temperatures. In actual geothermal system operations, heat source temperature rises or falls due to an imbalance of heating and cooling energy usage. Problems of source side temperature result in reduced geothermal system performance. The purpose of this study is to develop hybrid geothermal system operation technology to stabilize temperature and improve system performance by utilizing auxiliary heat source system. The auxiliary heat source system is operated by comparing the performance when operating the geothermal heat pump system alone and the performance when operating the hybrid geothermal heat pump system. The performance of a hybrid geothermal system is determined by the circulating water temperature of the geothermal system and the circulating water temperature of the auxiliary heat source system. Hybrid geothermal heat pump system performance is predicted through numerical analysis and collection of hybrid geothermal system performance data at various temperature ranges through field test. An operating method was developed using the predicted performance as the changeover operating point of the hybrid geothermal heat pump system. When applying the development and operation technology, it handled about $11 \%$ more load than the existing geothermal system operation. The addition of an auxiliary heat source increases the initial investment cost compared to the existing geothermal system, but decreases energy consumption, confirming that the initial investment cost of 15.3 years is recovered.
\end{abstract}

Keywords: hybrid geothermal heat pump system; changeover operating method; performance prediction; field test

\section{Introduction}

Commonly used geothermal systems are designed and operated independently by separating the geothermal system and other heat source systems. Most buildings do not use consistent cooling and heating throughout the year. When the amount of cooling used increases, the temperature of the existing geothermal system increases with increasing number of years of use. In contrast, the temperature drops when the amount of heating is high. This deteriorates the performance of the geothermal system. The problem of such a geothermal system can be solved by increasing the capacity of the heat exchanger of the geothermal system or increasing the borehole spacing. Such changes are 
difficult to apply practically because of the increase in initial investment cost from the increased heat exchanger capacity or increased required area of the ground due to the increase in borehole spacing.

The performance degradation problem of geothermal systems can be solved, and hybrid geothermal systems have been designed and operated economically. This study developed operating technology for hybrid geothermal systems. The geothermal system performance calculation criteria were developed using the heat source side temperature and performance prediction methods for the hybrid geothermal system operation to utilize geothermal system performance when selecting the operating conditions.

ASHRAE (1995) [1] described the reduction in the installation area and initial investment cost of the underground heat exchanger when the hybrid geothermal system was used, and Kavanaugh and Ratterty (1997) [2] discussed the design of the geothermal system for the commercial and institutional buildings described. When designing a hybrid geothermal system, they stated that the capacity of the auxiliary heat source system should be designed according to the difference in the maximum load for heating and cooling. Through this, it is possible to prevent the occurrence of temperature problems on the side of the heat source due to differences in heating and cooling loads. Yavuzturk and Spitler (2000) [3] conducted a comparative study of hybrid geothermal system control strategies using simulation. An economics analysis was conducted to select the control strategy with the lowest cost. Wang (2012) [4] proposed a hybrid geothermal system combined with a solar system for office buildings and analyzed system performance through dynamic energy simulation. Zang (2015) [5] compared operation strategies to optimize the performance of hybrid geothermal systems for small office buildings; using the difference between the existing fluid temperature and wet bulb temperature of the ground loop as a control variable is a method of reducing the initial cost of the hybrid geothermal system.

There are many studies on the effects of the design method and use of hybrid geothermal systems. There is also a study on the control strategy of hybrid geothermal systems [6-18]. In most previous studies, the operation of hybrid geothermal systems utilizes temperature as an operating point. This study aims to develop operational technology that utilizes performance as a hybrid geothermal system changeover operating point. The operation of the auxiliary heat source of the hybrid geothermal system is determined by comparing the performance when operating the single geothermal system and the performance when operating the hybrid geothermal system. To this end, it aims to develop a hybrid geothermal system performance prediction technology using the heat source side temperature.

\section{Hybrid Geothermal Heat Pump System}

Geothermal systems are generally used as geothermal systems that are installed and operated independently of other heat source systems. The problem caused by the design technology of existing general geothermal systems, which are designed separately from the geothermal system and other heat source systems, is that the temperature increases with increasing number of years of use of the geothermal system caused by the characteristics of general buildings where the use of cooling and heating throughout the year is not constant. Rising or falling occurs, which results in performance degradation of the geothermal system. As shown in the Figure 1, when the cooling load is greater than the heating load, the underground temperature rises, and when the heating load is greater than the cooling load, the ground temperature decreases.

For buildings in which the geothermal system is operating, temperature changes were analyzed when the heating and cooling load is unbalanced. As shown in Figure 2, the analysis building is being used for office purposes, and the amount of cooling is higher than that of heating. An analysis of the operation data from 2015 to 2017 during the geothermal operation data collection period showed that the temperature on the heat source side of the geothermal system increases with increasing number of years of operation. This occurs when there is an imbalance between the cooling and heating loads of the building. Moreover, the temperature of the heat source side increases due to underground heat accumulation when the geothermal system is operated for a long time. 


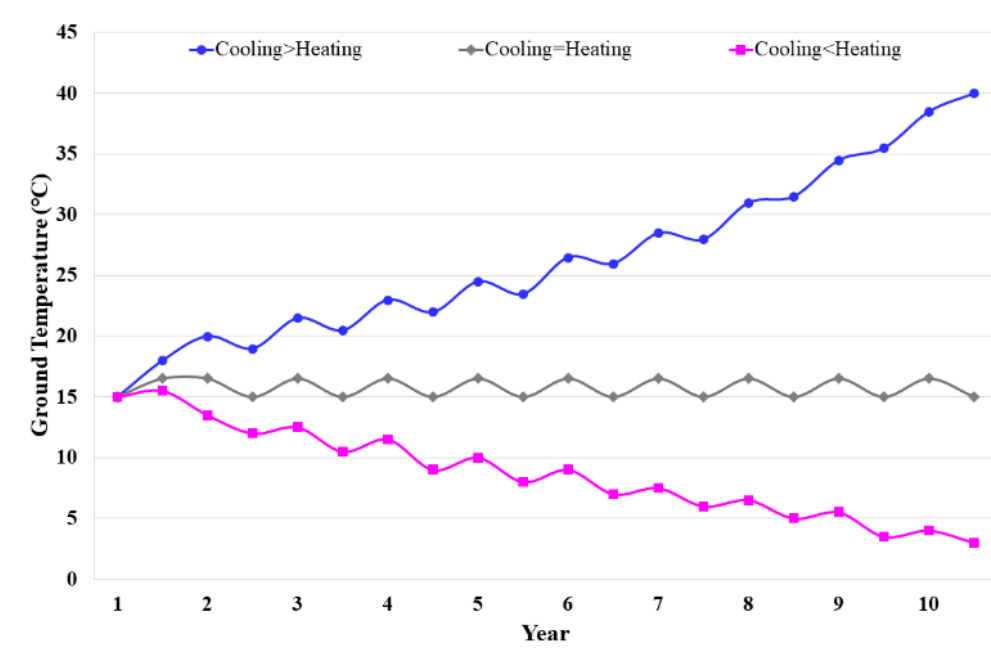

Figure 1. Ground temperature according to load.

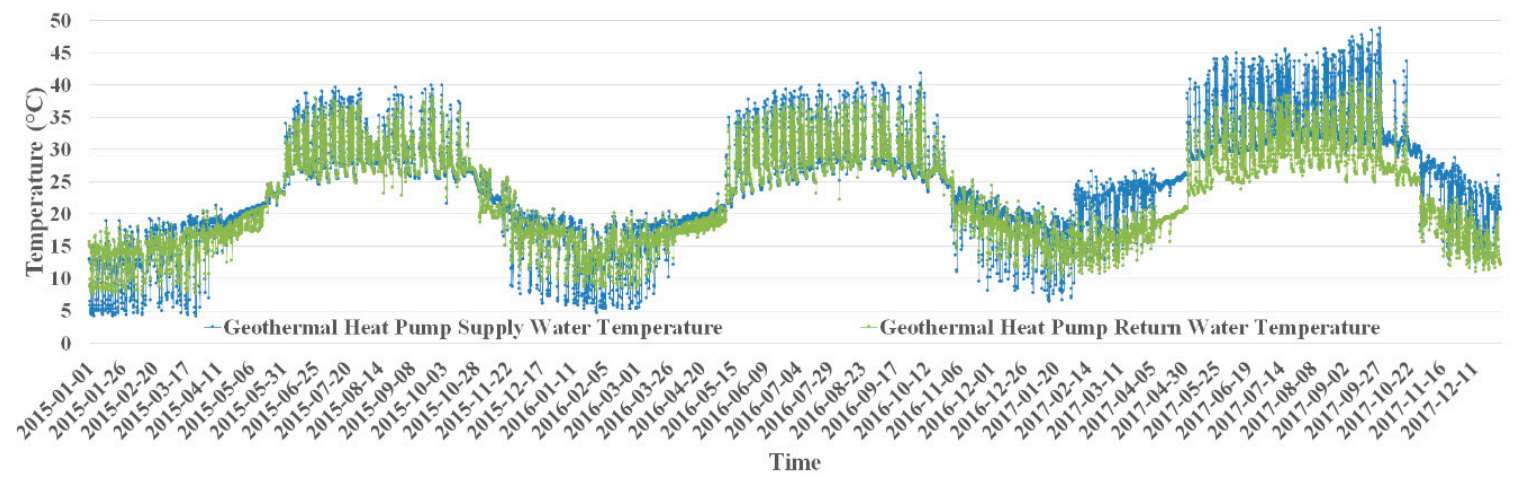

Figure 2. Source side temperature.

The hybrid geothermal system refers to a system in which a geothermal system and a heating auxiliary heat source, such as a boiler or solar heat, or a cooling auxiliary heat source, such as a cooling tower or a refrigerator, are connected and utilized. Figure 3 shows a hybrid geothermal heat pump system with an additional cooling auxiliary heat source. The underground temperature can be maintained in the optimal state by linking the auxiliary heat wall with the geothermal system, which can solve the problem of the occurrence of underground temperature problems and the degradation of the geothermal system performance caused by an imbalance of the heating and cooling load. The hybrid geothermal system is capable of reducing the number or size of heat exchangers. Moreover, it has an economic advantage by reducing the initial installation cost and installation area of the geothermal system.

In the P-h (Pressure-Enthalpy) diagram of hybrid geothermal heat pump system in Figure 4, the condenser line goes down from $a-b$ to $a^{\prime}-b^{\prime}$ due to the addition of low-temperature water from the auxiliary heat source during cooling operation, reducing the amount of heat from the compressor. As a result, cooling COP (Coefficient of Performance) increases when operating hybrid geothermal systems rather than geothermal systems.

In the P-h diagram of the hybrid geothermal heat pump system in Figure 5, the evaporator line rises from $\mathrm{C}-\mathrm{D}$ to $\mathrm{C}^{\prime}-\mathrm{D}^{\prime}$ due to the addition of high temperature water from the auxiliary heat source during cooling operation, and the compressor heat quantity decreases. As a result, heating COP increases when operating hybrid geothermal systems rather than geothermal systems. 


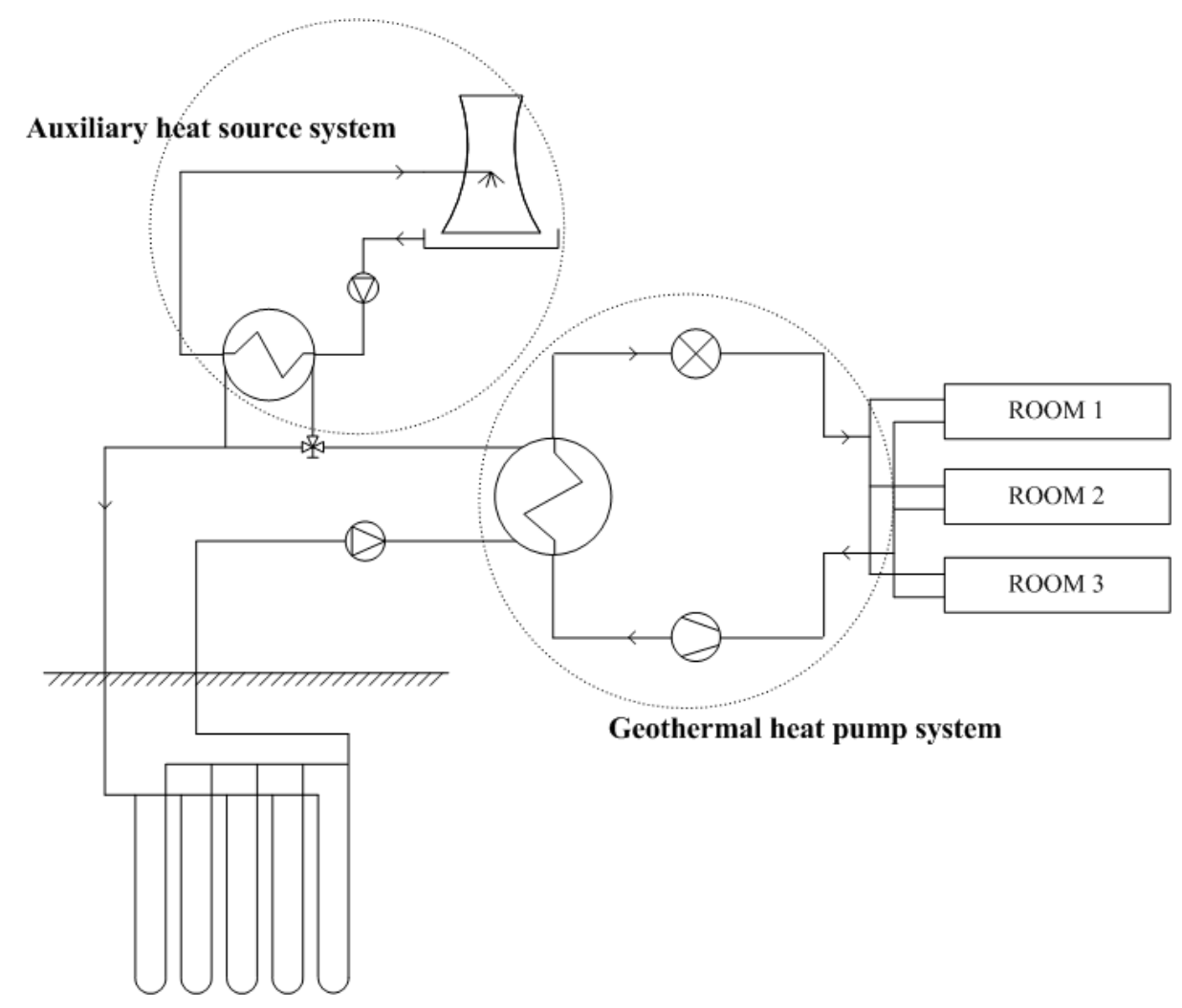

Figure 3. Hybrid geothermal heat pump system.

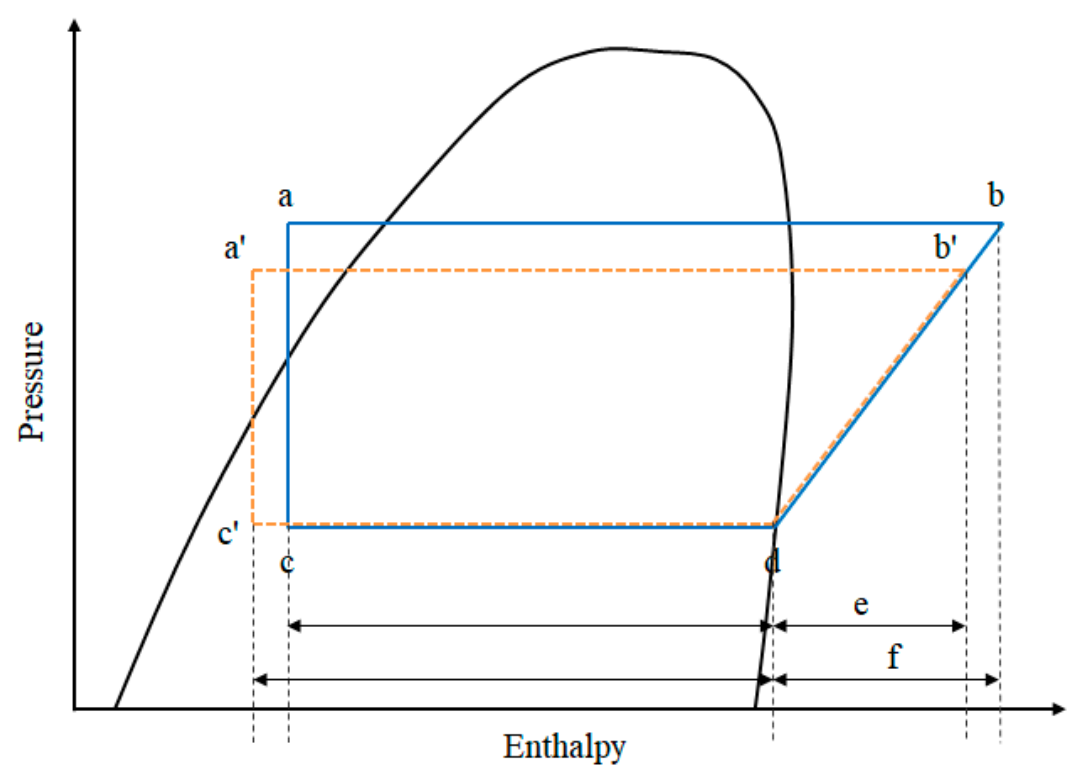

Figure 4. P-h (Pressure-Enthalpy) diagram of cooling operation. 


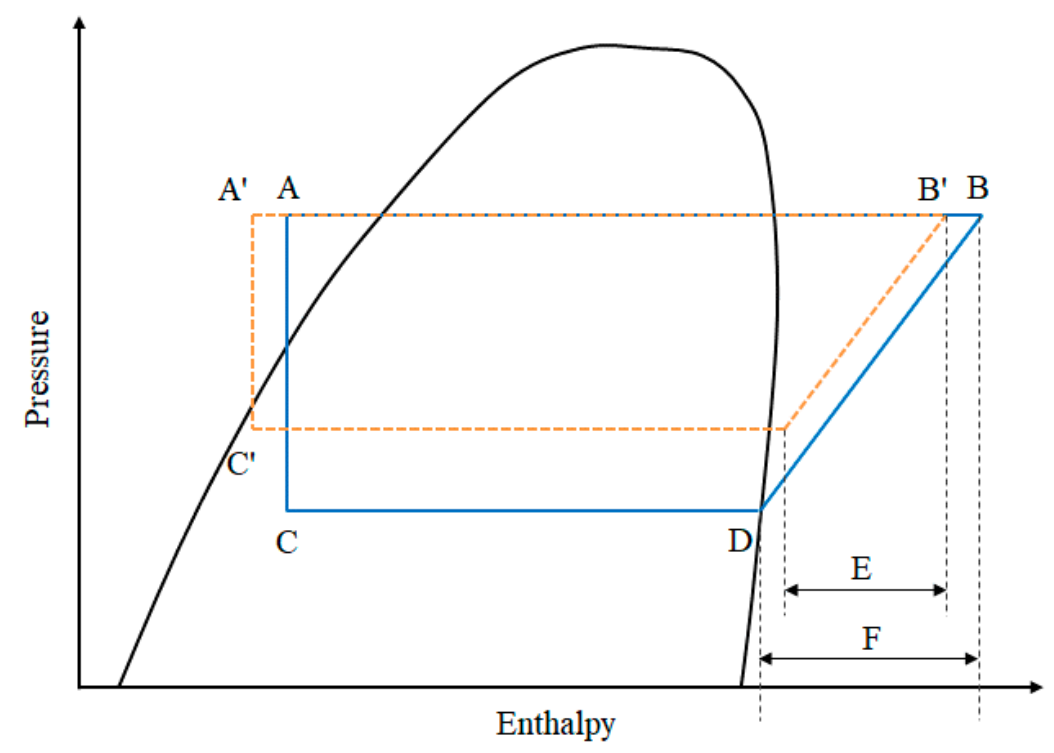

Figure 5. P-h diagram of heating operation.

\section{Performance Prediction of Hybrid Geothermal Heat Pump System through Field Test and Numerical Analysis}

The existing general hybrid geothermal heat pump system operation technology is a method of determining whether to operate the hybrid system based on the temperature at the inlet side of the heat source. It is theoretically expected that it can solve the problem of performance degradation caused by an increase in the inlet temperature on the heat source side that occurs during cooling operation of the hybrid geothermal heat pump system. When using the existing operating method, it cannot be directly confirmed that the performance is improved compared to the single operation of the geothermal heat pump system. Therefore, in this study, the performance of the system is used as a changeover operating point for determining the operation of the hybrid geothermal heat pump system. For this, this study attempts to predict the performance of hybrid geothermal systems. Through field tests, data related to the performance of the geothermal heat pump system under various conditions are collected, and performance predictions are made through numerical analysis. The performance of the hybrid geothermal system is determined by the geothermal circulating water temperature and the circulating water temperature of the auxiliary heat source. The performance of the hybrid geothermal heat pump system is predicted by considering the temperature change in the inlet side of the geothermal system heat source by the auxiliary heat source.

\subsection{Introduction of Field Test}

In order to predict the performance of the hybrid geothermal heat pump system, a field test was conducted to analyze the performance according to temperature conditions not provided by the manufacturer. The summary of the heat pump used in the field test is shown in Table 1.

Table 1. Summary of heat pump.

\begin{tabular}{ccc}
\hline Classification & Cooling & Heating \\
\hline Capacity $(\mathrm{kW})$ & 190.61 & 178.93 \\
Power $(\mathrm{W})$ & 38.03 & 44.52 \\
Flow Rate $(\mathrm{LPM})$ & 600 & 600 \\
COP & 5.01 & 4.02 \\
\hline
\end{tabular}

${ }^{*}$ Coefficient of Performance. 
A constant temperature tank is connected to the heat pump to simulate the heat source, load side, and heat source side for performance tests according to the changes in temperature, and it is used to supply cooling and heating heat sources and maintain the temperature through an air-cooled auxiliary heat source. Table 2 gives a summary of the experimental system. Figures 6 and 7 presents the equipment used in the field experiment.

Table 2. Summary of auxiliary system.

\begin{tabular}{ccc}
\hline Classification & Cooling & Heating \\
\hline Heat source tank & 18.7 ton & Circulation flow rate on heat source side: 5 -100 Ton \\
\hline Load tank & 18.7 ton & Circulation flow rate on load side: 5 -100 Ton \\
\hline Auxiliary heat source & $10 \mathrm{HP}$ & Air-cooled heat pump \\
\hline
\end{tabular}

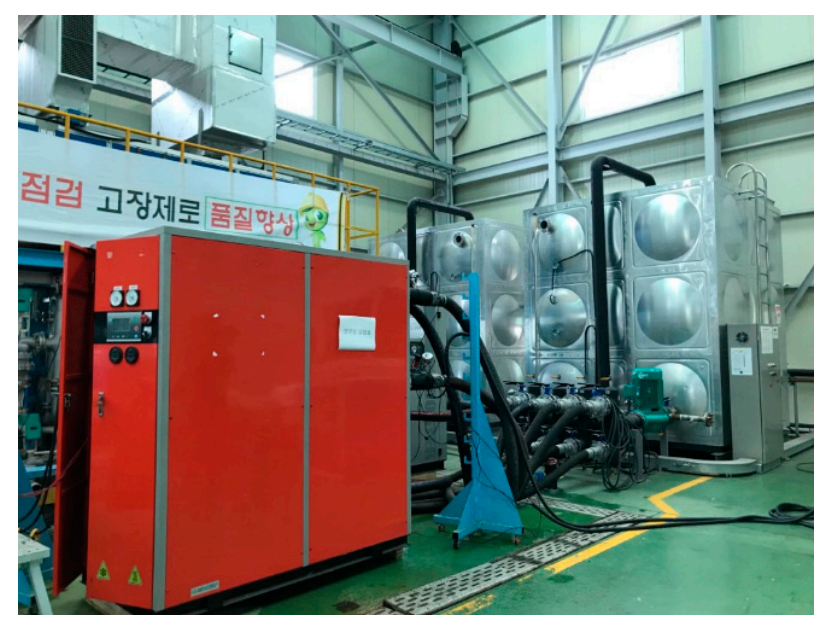

Figure 6. Test bed.

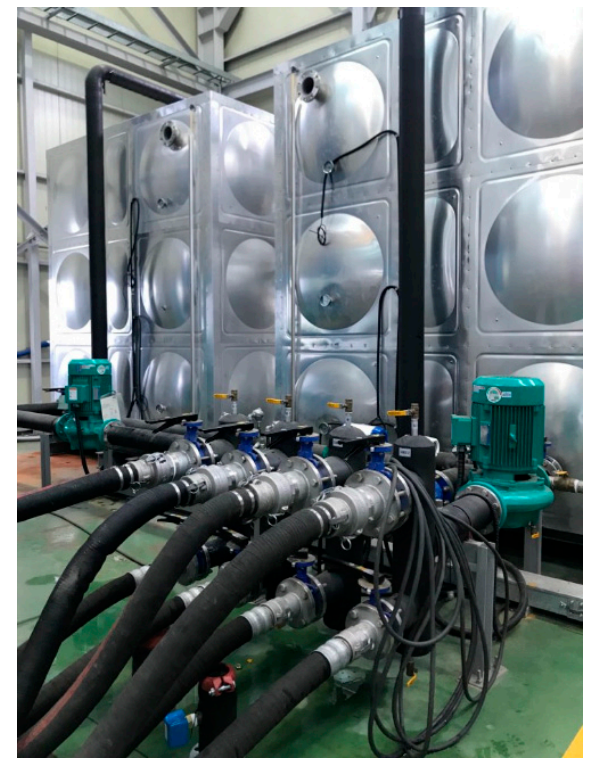

(a) Heat source and load tank

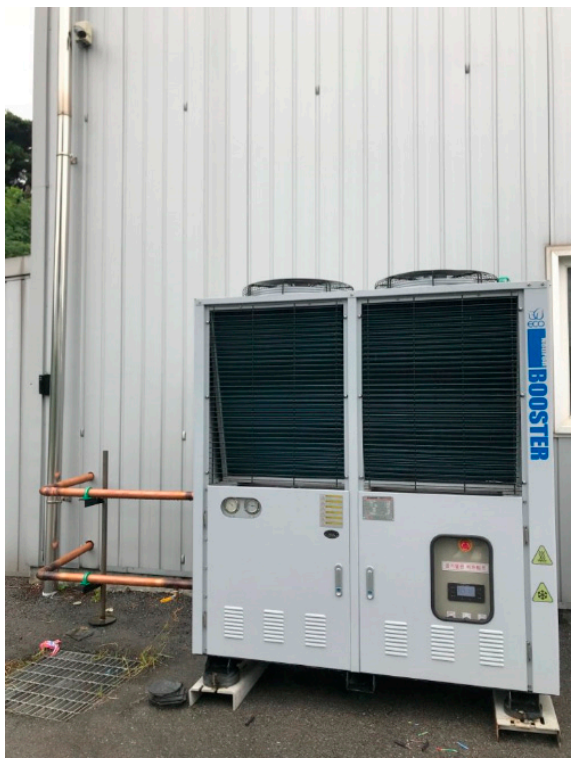

(b) Auxiliary heat source system

Figure 7. System of test bed.

For performance evaluation, the factors affecting the performance of geothermal heat pumps, such as the difference in inlet and outlet temperature, flow rate, and power consumption, and the 
temperature of the outside air are measured every minute. The heat source and load-side inlet and outlet temperatures are stored using a data logger connected to an RTD (Resistance Temperature Detector) temperature sensor. The flow rate is measured through a thermostat system on the load and heat source side and a flow meter installed in the water pipeline. The power consumption is measured by installing a watt-hour meter in the heat pump. Before data collection, the standard uncertainty of the temperature sensor and flow rate meter was calculated. The measurement uncertainty of temperature was repeated five times each under $10{ }^{\circ} \mathrm{C}, 30^{\circ} \mathrm{C}$, and $50^{\circ} \mathrm{C}$ conditions. The flow rate was measured three times each from $15 \mathrm{~m}^{3} / \mathrm{h}$ to $250 \mathrm{~m}^{3} / \mathrm{h}$. As for the measurement uncertainty, as shown in Table 3 , the uncertainty of the temperature measuring device is 0.2 and the uncertainty of the flow meter is $0.26 \sim 0.32$.

Table 3. Measurement uncertainty.

\begin{tabular}{cc}
\hline Classification & Uncertainty (\%) \\
\hline Temperature & 0.2 \\
Flow Rate & $0.26-0.32$ \\
\hline
\end{tabular}

The performance under a broader range of heat-source-side inlet-temperature conditions, considering the actual operating situation, is evaluated by measuring each item according to the heat-source-side inlet temperature in the range of $8.1-26.8^{\circ} \mathrm{C}$ during heating operation and $20-49{ }^{\circ} \mathrm{C}$ during cooling operation. This study aims to predict the performance of hybrid geothermal systems through numerical analysis of data obtained through field tests.

\subsection{Performance Prediction through Field Test and Numerical Analysis}

In this study, performance prediction is made in order to use the performance as a changeover point in the operating method of the hybrid geothermal heat pump system. Hybrid geothermal heat pump system performance is predicted through numerical analysis of performance-related data based on field test. Among the factors that have an important influence on the performance of a geothermal heat pump system, performance is predicted by using the heat source side temperature and the load-side temperature which can be easily monitored. When operating the hybrid geothermal heat pump system, the inlet temperature on the source side of the geothermal system is changed by the auxiliary heat source system. Therefore, in this study, the temperature at the source side of the geothermal system is calculated according to the operation of the auxiliary heat source system. The hybrid geothermal system performance is predicted through the changed geothermal system heat source and load-side temperatures.

During the cooling operation of the hybrid geothermal heat pump system, the temperature of the supplied circulating water is lowered through heat exchange between the circulating water at the source side and the cooling water at the cooling tower. Assuming that the heat exchange efficiency of the circulating water and the cooling water on the heat source side of the geothermal heat pump system is $100 \%$, the amount of heat exchanged is the same. This is the same as Equation (1).

$$
\left(t_{c w, i}-t_{c w, o}\right) m_{c w}=\left(t_{s, i}-t_{s, o}\right) m_{s}
$$

Through this, the inlet temperature on the heat source side of the geothermal heat pump system changed according to the operation of the auxiliary heat source shown in Equation (2).

$$
t_{s, o}=\frac{t_{s, i}-\left(t_{c w, i}-t_{c w, o}\right) m_{c w}}{m_{s}}
$$

In order to predict the performance of the hybrid geothermal system, a numerical analysis of data based on field experiments was performed. The relationship between the source side inlet temperature 
and performance was analyzed, and the analysis result is shown in Figure 8. Performance deteriorates as the inlet temperature on the heat source side increases.

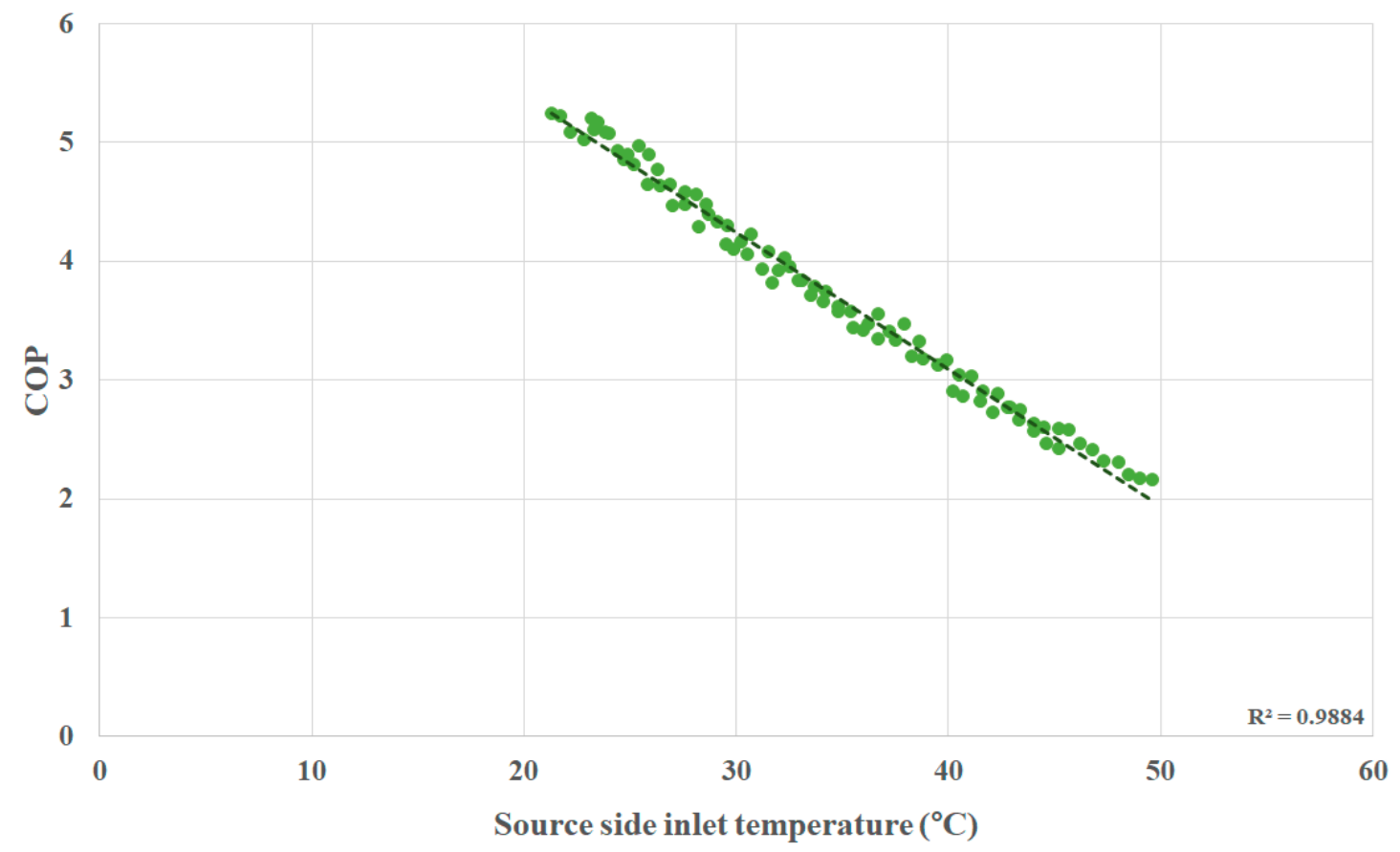

Figure 8. Performance according to source-side inlet temperature during cooling operating.

The relationship between load-side inlet temperature and performance is shown in Figure 9. It is possible to check the phenomenon opposite to the temperature on the heat source side.

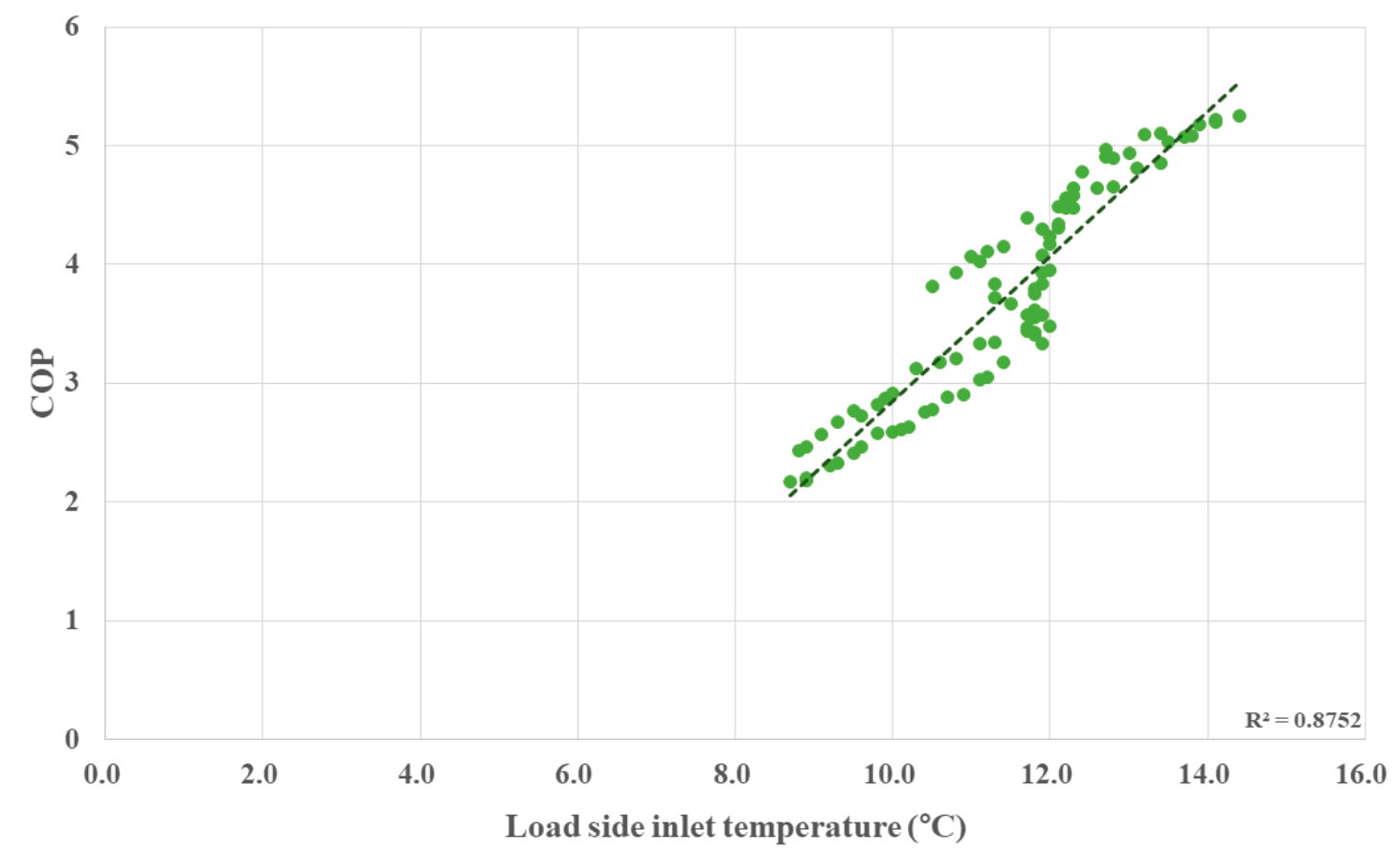

Figure 9. Performance according to load-side inlet temperature during cooling operating. 
The performance prediction method was derived through multiple regression analysis between the performance and the heat source side and the load-side temperature. The performance prediction equation is shown in Equation (3).

$$
C O P=-9.46+3.17 t_{L}-0.13\left(t_{L}\right)^{2}-0.29 t_{S, 0}+0.003\left(t_{S, 0}\right)^{2}
$$

Figure 10 shows the performance prediction verification results of the hybrid geothermal heat pump system. Table 4 shows the error analysis results, the relative error was $-6-12 \%$ and the $\mathrm{R}^{2}$ was 0.9537.

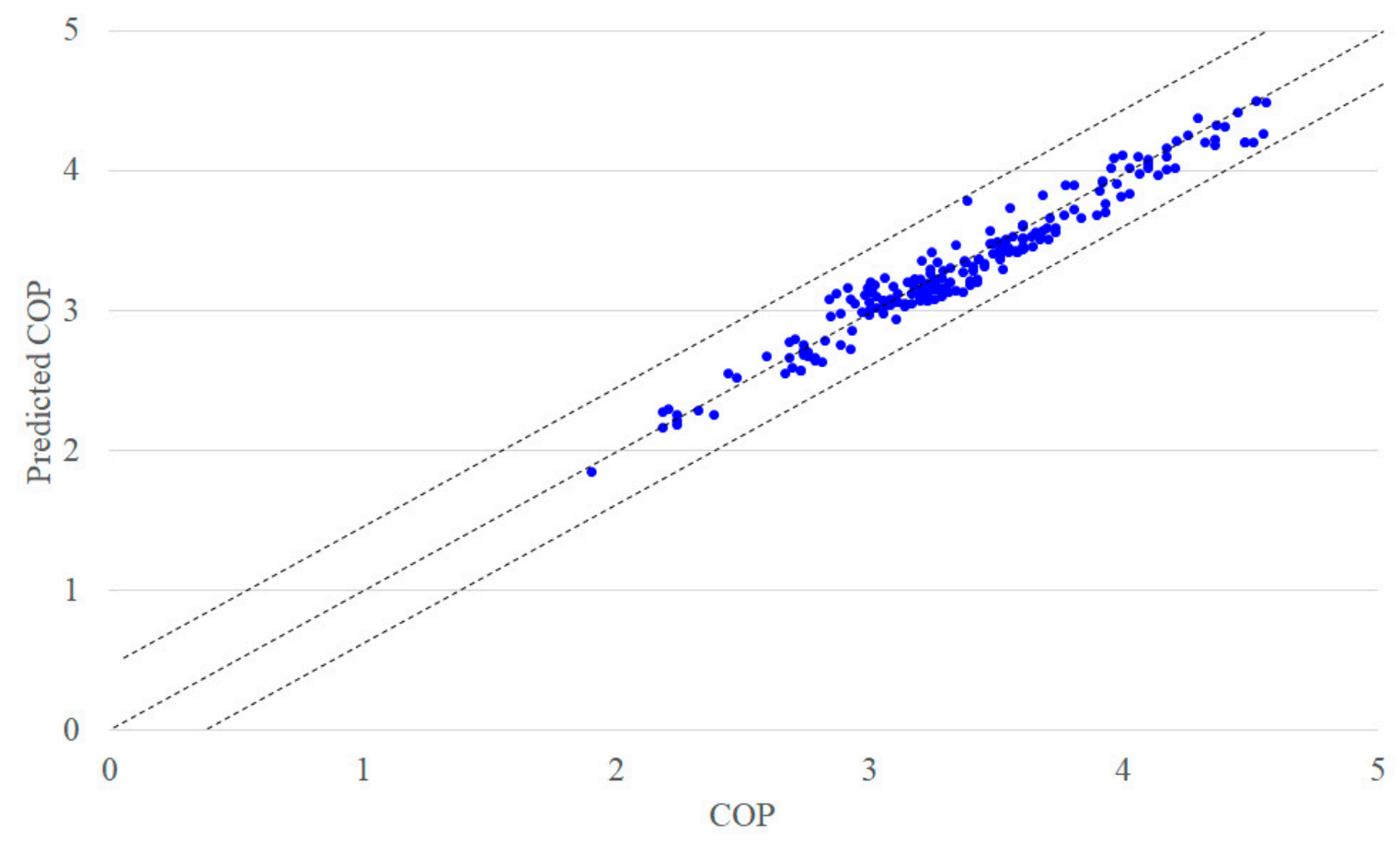

Figure 10. Performance prediction verification.

Table 4. Error analysis of prediction model.

\begin{tabular}{cccc}
\hline RMSE $^{*}$ & $\mathbf{R}^{\mathbf{2}}$ & Absolute Error & Relative Error \\
\hline 0.1183 & 0.9537 & $0.04-0.40$ & $-0.06-0.12$ \\
\hline \multicolumn{4}{c}{ * Root Mean Square Error. }
\end{tabular}

\section{Development of Changeover Operating Method Based on Performance Prediction of Hybrid Geothermal Heat Pump Systems}

\subsection{Development of Changeover Operating Method}

In this study, a changeover operating method based on the performance prediction of hybrid geothermal heat pump system was developed for efficient geothermal heat pump system operation. When operating a geothermal system, system performance is used as the changeover point of hybrid system operation. When a geothermal heat pump system is operated alone without an auxiliary heat source, and when performance decreases due to an increase in temperature on the heat source side, the hybrid geothermal system is operated when it is determined that performance improvement is possible by operating the hybrid system. The developed hybrid geothermal heat pump system operation algorithm is shown in Figure 11. 


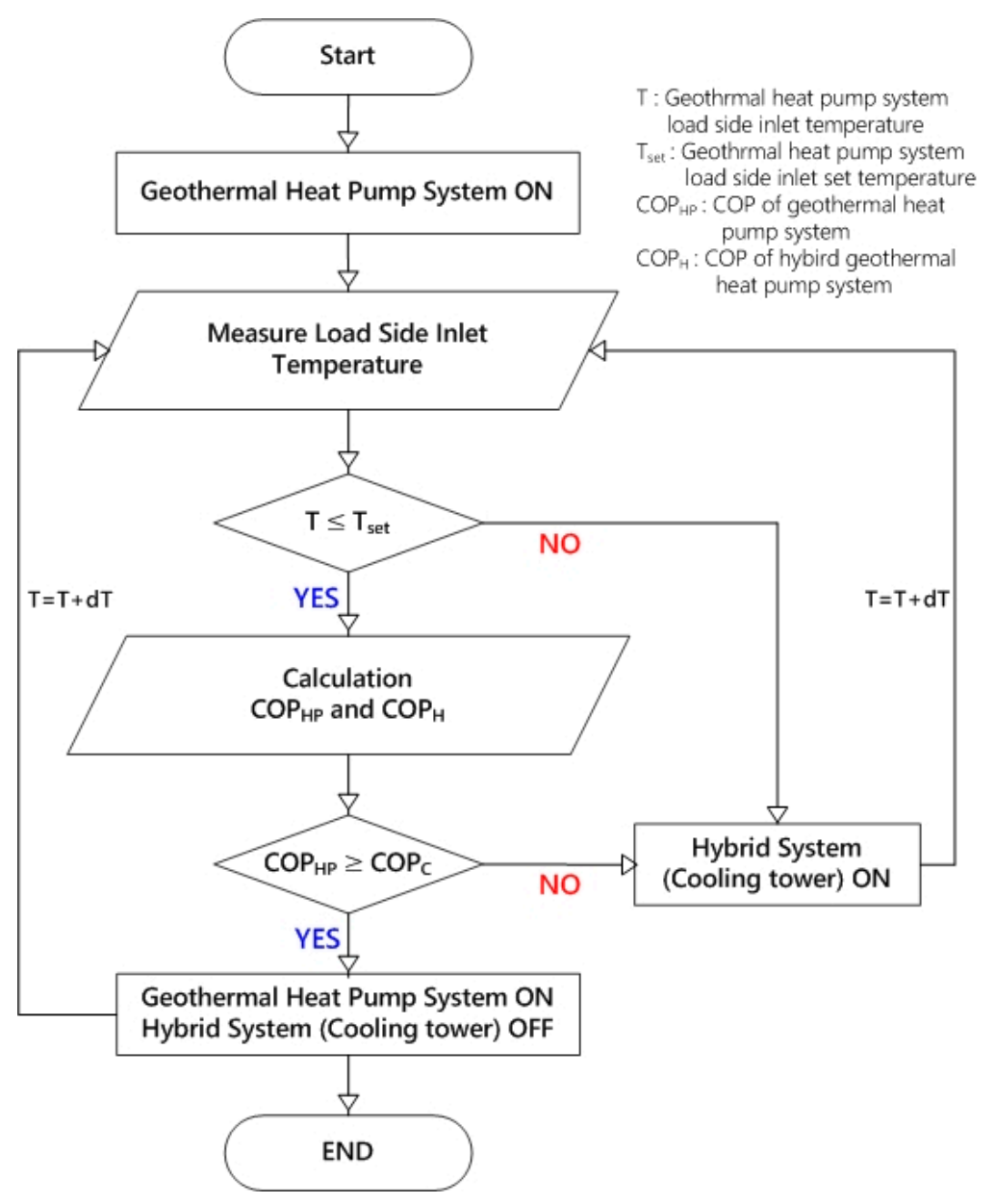

Figure 11. Algorithm of hybrid geothermal system operation.

When the system is stabilized after the start of the geothermal system cooling operation, the geothermal system has sufficient capacity to handle the load generated from the building if the inlet temperature on the load side is lower than or equal to the set temperature, and the geothermal system continues to operate. Hybrid system operation is started when it is judged that the load generated from the building is insufficient for the geothermal system to be in charge, or when it is determined that operating a hybrid system will improve performance rather than continue to operate the geothermal system. After the operation of the hybrid system, after a certain period ( $\mathrm{dt}=10 \mathrm{~min})$, the operation of the hybrid system is judged, and the operation continues if necessary.

(1) Operation of geothermal heat pump system

When a load occurs, the geothermal heat pump system operates alone. If the load-side inlet temperature of the geothermal heat pump system is lower than the design reference temperature, the geothermal heat pump system continues to operate alone $\left(T_{\text {set }}-d<T \leq T_{\text {set }}+d\right)$.

(2) Changeover operation of hybrid geothermal heat pump system

When the load-side inlet temperature of the geothermal heat pump system is higher than the design reference temperature, the auxiliary heat source system is operated, and the hybrid geothermal heat pump system is operated $\left(T>T_{\text {set }}+d\right)$. The performance of the hybrid geothermal heat pump system is predicted using the proposed hybrid geothermal heat pump system performance prediction method. If the performance of the hybrid system is higher than that of the single operation of the geothermal heat pump system, the operation of the hybrid geothermal heat pump system continues 
$\left(C O P_{H} \geq C O P_{H P}\right)$. If the performance of the geothermal heat pump alone is better, the hybrid geothermal heat pump system is stopped $\left(C O P_{H P}>C O P_{H}\right)$.

\subsection{Application of Changeover Operating Method}

The changeover operating method of the hybrid geothermal heat pump system was applied to compare the performance and economic analysis between the general geothermal system and the hybrid geothermal heat pump system through simulation. The target building is an office building, and the information is shown in Table 5.

Table 5. Target building information.

\begin{tabular}{ccc}
\hline \multicolumn{2}{c}{ Classification } & Contents \\
\hline \multirow{3}{*}{ Buildings } & Location & Seoul, Korea \\
& Building stories & 10 floors above ground \\
& Building purpose & Office \\
& Gross floor area & $12,421 \mathrm{~m}^{2}$ \\
\hline
\end{tabular}

The target building uses a geothermal heat pump system and a cooling tower as an auxiliary heat source, and the information on the geothermal heat pump system is shown in Table 6, and the information on the auxiliary heat source system is shown in Table 7.

Table 6. Geothermal heat pump system information.

\begin{tabular}{cccc}
\hline \multicolumn{1}{c}{ Classification } & \multicolumn{2}{c}{ Contents } \\
\hline & Quantity & 5 \\
Geothermal heat pump & Cooling & Heating \\
& Capacity $(\mathrm{kW})$ & 175 & 172 \\
& Power consumption $(\mathrm{kW})$ & 46.5 & 45.6 \\
& Entering source & 25 & 5 \\
& temperature $\left({ }^{\circ} \mathrm{C}\right)$ & 12 & 40 \\
\hline \multirow{3}{*}{ Circulation pump } & Supplied temperature $\left({ }^{\circ} \mathrm{C}\right)$ & 12 & \multicolumn{2}{c}{6} \\
& Quantity & \multicolumn{2}{c}{55} \\
& Flow rate $\left(\mathrm{m}^{3} / \mathrm{h}\right)$ & 5.5 \\
\hline
\end{tabular}

Table 7. Auxiliary heat source system information.

\begin{tabular}{ccc}
\hline & Classification & Contents \\
\hline \multirow{3}{*}{ Cooling tower } & Quantity & 1 \\
& Capacity $(\mathrm{CRt})$ & 150 \\
& Flow rate $\left(\mathrm{m}^{3} / \mathrm{h}\right)$ & 99 \\
\hline & Power consumption $(\mathrm{kW})$ & 18.5 \\
\hline \multirow{3}{*}{ Circulation pump } & Quantity & 2 \\
& Flow rate $\left(\mathrm{m}^{3} / \mathrm{h}\right)$ & 25 \\
& Power consumption $(\mathrm{kW})$ & 10 \\
\hline
\end{tabular}

\subsubsection{Performance Analysis}

To analyze the performance of the changeover operating method of hybrid geothermal heat pump system, COP is compared when operating a general geothermal system and a hybrid system. In addition, the load that could not be solved due to the shutdown of the geothermal system due to the decrease in performance due to the temperature increase on the heat source side is compared. The comparison results are shown in Table 8. 
During the cooling operation period of the geothermal heat pump system, if the inlet temperature on the source side exceeds $40^{\circ} \mathrm{C}$, the operation is stopped. When operating a general geothermal heat pump system, due to the increase in temperature on the heat source side, the system shutdown time is $76 \mathrm{~h}$, which is $8.7 \%$ of the total cooling demand. The unresolved load due to performance degradation and shutdown is $55,030 \mathrm{kwh} / \mathrm{hr}$, which is $11.9 \%$ of the total cooling load. When applying the changeover operating method of hybrid geothermal heat pump system, the operating downtime was $5 \mathrm{~h}$, which was reduced by $8 \%$ compared to the operation of the general geothermal heat pump system, and the unresolved load decreased by about $11 \%$.

Table 8. Performance comparison of geothermal system and hybrid geothermal heat pump system.

\begin{tabular}{cccc}
\hline & Category & $\begin{array}{c}\text { General Geothermal } \\
\text { Heat Pump System }\end{array}$ & $\begin{array}{c}\text { Hybrid Geothermal } \\
\text { Heat Pump System }\end{array}$ \\
\hline \multirow{3}{*}{ Operating Time } & Required operating time (hr/yr) & 870 & 870 \\
& System downtime $(\mathrm{hr} / \mathrm{yr})$ & 76 & 5 \\
& System down rate & $8.7 \%$ & $0.6 \%$ \\
\hline \multirow{3}{*}{ Load } & Total load $(\mathrm{kWh} / \mathrm{yr})$ & 461,121 & 461,121 \\
& Unhandled load $(\mathrm{kWh} / \mathrm{yr})$ & 55,030 & 4039 \\
& Unhandled load rate & $11.9 \%$ & $0.9 \%$ \\
\hline
\end{tabular}

During the operation of a general geothermal heat pump system, there was a date that the system was suspended for one day. On the other hand, in the case of hybrid system operation, the operation is stopped only at some time, so the building user does not feel great inconvenience or cause a major problem in operation. Figure 12 shows the COP analysis result when operating a hybrid system. During the operation of the geothermal heat pump system, the point at which the hybrid geothermal heat pump system operation starts, due to the COP being higher when the hybrid geothermal heat pump system is operated, is called the changeover operating point. During the entire analysis period, when the geothermal heat pump system was operated, the COP ranged from 1.8 to 4.1 and the hybrid geothermal heat pump system operated from the lowest 3 to the highest 4.5 .

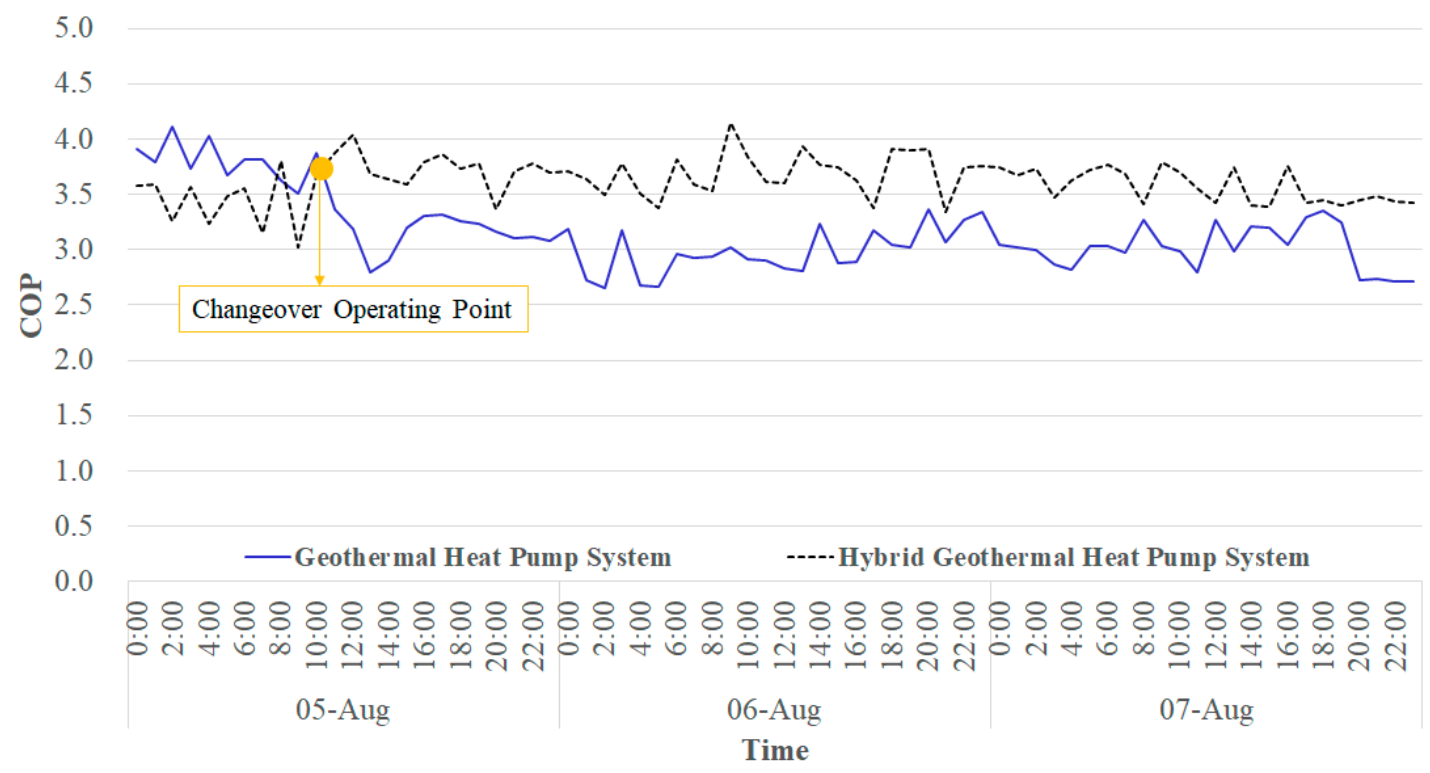

Figure 12. Analysis of COP.

\subsubsection{Economic Analysis}

In this study, the analysis of economic is analyzed through the initial investment cost method based on investment cost and operating cost. In the case of a hybrid geothermal heat pump system, 
the initial investment cost increases with the addition of an auxiliary heat source. The annual electricity usage and cost are shown in Table 9.

Table 9. Annual electricity usage and cost.

\begin{tabular}{ccc}
\hline Classification & Geothermal Heat Pump System & Hybrid Geothermal Heat Pump System \\
\hline Annual cooling operation usage $(\mathrm{kWh} / \mathrm{yr})$ & 148,972 & 119,994 \\
\hline Annual heating operation usage $(\mathrm{kWh} / \mathrm{yr})$ & 60,948 & 61,002 \\
\hline Annual cooling electricity cost $(\mathrm{KRW} / \mathrm{yr})$ & $21,456,625$ & $17,314,349$ \\
\hline Annual heating electricity cost $(\mathrm{KRW} / \mathrm{yr})$ & $8,841,674$ & $8,849,515$ \\
\hline Annual electricity cost $(\mathrm{KRW} / \mathrm{yr})$ & $30,298,299$ & $28,173,134$ \\
\hline
\end{tabular}

The economic analysis results are shown in Table 10.

Table 10. Results of economic analysis of hybrid geothermal heat pump system.

\begin{tabular}{ccc}
\hline Classification & Geothermal Heat Pump System & Hybrid Geothermal Heat Pump System \\
\hline Additional initial investment cost (KRW) & - & $32,473,497$ \\
\hline Annual electricity cost (KRW/yr) & $30,298,299$ & $28,173,134$ \\
\hline Difference of electricity cost (KRW/yr) & - & $-2,125,165$ \\
\hline Simple investment cost payback period (yr) & - & 15.3 \\
\hline
\end{tabular}

An additional KRW 32,473,497 is used compared to the general geothermal heat pump system. The operating cost is calculated based on the annual electricity consumption used for heating and cooling operations. Electricity rates are based on KEPCO (Korea Electric Power Corporation)'s electricity rates. Compared to general geothermal heat pump systems, power consumption is reduced because it can achieve high performance due to the decrease in temperature on the side of the heat source due to operation of the auxiliary heat source. Compared to the previous operation, it was reduced by KRW 2,125,165, resulting in a simple initial investment payback period of 15.3 years.

\section{Conclusions}

The purpose of this study is to develop a hybrid geothermal heat pump system operation method that utilizes performance as a changeover operating point to stabilize temperature and improve system performance. Hybrid geothermal heat pump system performance is predicted through numerical analysis of performance-related data based on field tests. Through the application of the developed changeover operating method of hybrid geothermal heat pump system, the performance analysis and economic analysis of the geothermal heat pump system were conducted. The results of this study are as follows.

(1) Performance is predicted through numerical analysis of data related to the performance of geothermal heat pump systems under various conditions collected through field tests. The performance of a hybrid geothermal system is determined by the geothermal circulation water temperature and the circulating water temperature of the auxiliary heat source. The performance of the hybrid geothermal heat pump system is predicted by considering the temperature change at the inlet side of the geothermal system heat source by the auxiliary heat source.

(2) In this study, a changeover operating method based on the performance prediction of hybrid geothermal heat pump system was developed for efficient geothermal heat pump system operation. When operating a geothermal system, system performance is used as the changeover point of hybrid system operation. When a geothermal heat pump system is operated alone without an auxiliary heat source, and when performance decreases due to an increase in temperature on the heat source side, the hybrid geothermal system is operated when it is determined that performance improvement is possible by operating the hybrid system. 
(3) The developed hybrid geothermal heat-pump-system operation method was verified though performance and economic analysis. When applying the changeover operating method of the hybrid geothermal heat pump system, the operating downtime was $5 \mathrm{~h}$, which was reduced by $8 \%$ compared to the operation of the general geothermal heat pump system, and the unresolved load decreased by about $11 \%$. Compared to the geothermal heat pump system operation, operating cost was reduced by KRW 2,125,165 and initial cost was increased by KRW 32,473,497, resulting in a simple initial investment payback period of 15.3 years.

Author Contributions: All authors contributed to this work. J.-H.S. investigated and wrote the original draft. Y.-H.C. carried out project administration and supervisor. Y.-B.S. gave conceptual advice. Y.-I.K. gave conceptual advice and provided study materials. All authors have read and agreed to the published version of the manuscript.

Funding: This research was funded by the 2019 Yeungnam University Research Grant (219A061027).

Conflicts of Interest: The authors declare no conflict of interest.

\section{Nomenclature}

$t_{S, i} \quad$ Source-side inlet temperature of geothermal heat pump system before heat exchange, ${ }^{\circ} \mathrm{C}$

$t_{S, 0} \quad$ Source-side inlet temperature of geothermal heat pump system after heat exchange, ${ }^{\circ} \mathrm{C}$

$t_{c w, i} \quad$ Cooling water inlet temperature, ${ }^{\circ} \mathrm{C}$

$t_{c w, o} \quad$ Cooling water outlet temperature, ${ }^{\circ} \mathrm{C}$

$m_{c w} \quad$ Flow rate of cooling water $(\mathrm{L} / \mathrm{m})$

$m_{S} \quad$ Flow rate of circulation water on geothermal heat pump system $(\mathrm{L} / \mathrm{m})$

$t_{L} \quad$ Load-side inlet temperature of geothermal heat pump system, ${ }^{\circ} \mathrm{C}$

\section{References}

1. ASHRAE. Commercial/Institutional Ground-Source Heat Pumps Engineering Manual; American Society of Heating, Refrigerating and Air-Conditioning Engineers, Inc.: Atlanta, AP, USA, 1995.

2. Stephen, P.K.; Kevin, R. Ground-Source Heat Pump: Design of Geothermal Systems for Commercial and Institutional Buildings; Refrigerating and Air-Conditioning Engineers, ASHRAE: Peachtree Corners, GA, USA, 1997.

3. Yavuzturk, C.; Spitler, J.D. Comparative study of operationg and control strategies for hybrid ground-source heat pump systems using a short time step simulation model. AHSRAE Trans. 2000, 106, 192-209.

4. Wang, E.; Fung, A.S.; Qi, C.; Leong, W.H. Performance prediction of a hybrid solar ground-source heat pump system. Energy Build. 2012, 47, 600-611. [CrossRef]

5. Zhang, Q.; Lv, N.; Chen, S.; Shi, H.; Chen, Z. Study on Operating and Control Strategies for Hybrid Ground Source Heat Pump System. Procedia Eng. 2015, 121, 1894-1901. [CrossRef]

6. Shin, J.S.; Park, J.W.; Kim, S.H. Measurement and Verification of Integrated Ground Source Heat Pumps on a Shared Ground Loop. Energies 2020, 13, 1752. [CrossRef]

7. Yiqun, H.L.F.R.P.; Zhizhong, H. Review and Development of Hybrid Ground-Source Heat Pump System. Refrig. Air Cond. 2011, 25, 518-525.

8. Kavanaugh, S.P. A design method for hybrid ground source heat pumps. ASHRAE Trans. 1998, 104, 691-698.

9. Yang, H.; Cui, P.; Fang, Z. Vertical-borehole ground-coupled heat pumps: A review of models and systems. Appl. Energy 2010, 87, 16-27. [CrossRef]

10. Liu, Z.; Li, Y.; Xu, W.; Yin, H.; Gao, J.; Jin, G.; Lun, L.; Jin, G. Performance and feasibility study of hybrid ground source heat pump system assisted with cooling tower for one oce building based on one Shanghai case. Energy 2019, 173, 28-37. [CrossRef]

11. Ozgener, O.; Hepbasli, A. Modeling and performance evaluation of ground source (geothermal) heat pump systems. Energy Build. 2007, 39, 66-75. [CrossRef]

12. Chiasson, A.; Yavuzturk, C. Assessment of the Viability of Hybrid Geothermal Heat Pump Systems with Solar Thermal Collectors. ASHRAE Trans. 2003, 109, 487.

13. Phetteplace, G.; Sullivan, W. Performance of a Hybrid Ground-Coupled Heat Pump System. ASHRAE Trans. $1998,104,763$. 
14. Ramamoorthy, M.; Jin, H.; Chaisson, A.D.; Spitler, J.D. Optimal Sizing of Hybrid Ground-Source Heat Pump Systems that Use a Cooling Pond as Supplemental Heat Rejector-A Systematic Simulation Approach. ASHRAE Trans. 2001, 107, 26-38.

15. Qi, Z.; Gao, Q.; Liu, Y.; Yan, Y.; Spitler, J. Status and Development of Hybrid Energy Systems from Hybrid Ground Source Heat Pump in China and Other Countries. Renew. Sustain. Energy Rev. 2014, 29, 37-51. [CrossRef]

16. Sohn, B.; Kwon, H.S. Performance Prediction on the Application of a Ground-Source Het Pump(GSHP) System in an Office Building. Korean J. Air-Cond. Refrig. Eng. 2014, 26, 409-415.

17. ASHRAE. ASHRAE Handbook-Systems and Equipment, Chapter 36; American Society of Heating, Refrigerating and Air-Conditioning Engineers, Inc.: Atlanta, AP, USA, 1996.

18. Song, G.Q.; Xu, X.H.; Wu, D. Control Strategy Study of Hybrid Ground-Source Heat Pump System. Refrig. Air Cond. 2013, 27, 280-283.

(C) 2020 by the authors. Licensee MDPI, Basel, Switzerland. This article is an open access article distributed under the terms and conditions of the Creative Commons Attribution (CC BY) license (http://creativecommons.org/licenses/by/4.0/). 